\title{
PENYULUHAN DAN PELATIHAN PEMASARAN DIGITAL, ADMINITRASI KEUANGAN DAN HAK KEKAYAAN INTELEKTUAL BAGI PELAKU UMKM DI DESA MADYOCONDRO
}

\author{
Betari Maharani ${ }^{*}$, Alfiana Yogi Saputri ${ }^{2}$, Abrianti Kusuma Wardani ${ }^{3}$, Wahyu Widi \\ Astuti $^{4}$, Wulan Lailatul A'idah', Febriansyah Aji Pangestu ${ }^{6}$ \\ Universitas Muhammadiyah Magelang, Indonesia1,2,3,4,5,6
}

Corresponding Author: Betari, (@betari.maharani@ummgl.ac.id

\section{ABSTRAK}

UMKM memiliki peranan yang penting dalam perekonomian Indonesia dan UMKM menjadi salah satu terobosan dalam mengurangi tingkat pengangguran serta meningkatkan perekonomian masyarakat. Di Dusun Dawunan, Desa Madyocondro, Kecamatan Secang, Kabupaten Magelang terdapat UMKM Kue Nopia Mirasa dan Kue Egg Roll Berkah Dua Putri.

ARTICLE INFO

Article history: Received

20 Januari 2022

Revised

25 Januari 2020

Accepted
30 Januari 2022

Pada pengembangan bisnisnya, kedua UMKM mengalami beberapa permasalahan seperti kurangnya pengetahuan dan pemahaman pelaku UMKM terhadap model pengembangan pemasaran melalui media sosial, sistem pembukuan keuangan dan hak kekayaan intelektual. Metode yang digunakan dalam kegiatan pengabdian ini adalah sosialisasi, pelatihan dan pendampingan. Setelah dilakukan beberapa kegiatan dalam program pengabdian, pengetahuan dan pemahaman pelaku UMKM terhadap model pengembangan pemasaran melalui media sosial, sistem pembukuan keuangan dan hak kekayaan intelektual mengalami peningkatan. Hal ini nampak dari perubahan sikap pelaku UMKM dalam hal keberlanjutan penggunaan media sosial sebagai media pemasaran dan melakukan pembukuan keuangan.

Kata Kunci: Usaha Mikro Kecil Menengah, pemasaran digital, pembukuan keuangan, hak kekayaan intelektual

How to Cite $\quad$ : Betari Maharani, Alfiana Yogi Saputri, Wardani, Arbianti Kusuma...et.al. (2022). Penyuluhan dan Pelatihan Pemasaran Digital, Administrasi Keuangan dan Hak Kekayaan Intelektual Bagi Pelaku UMKM di Desa Madyocondro. Taroa: Jurnal Pengabdian Masyarakat, 1(1), 52-5.

DOI : : https://doi.org/https://doi.org/10.52266/

Journal Homepage: https://ejournal.iaimbima.ac.id/index.php/

This is an open access article under the CC BY SA license

: https://creativecommons.org/licenses/by-sa/4.0/

\section{PENDAHULUAN}

$\mathrm{U}$ saha Mikro Kecil dan Menengah (UMKM) memiliki peranan penting dalam perekonomian di Indonesia. Keberadaan dan peran UMKM dalam perekonomian merupakan salah satu kunci dalam keberhasilan dalam menghadapi berbagai krisis maupun untuk memenuhi kebutuhan hidup masyarakat. Terbukti bahwa pada tahun 2021, kontribusi UMKM terhadap Produk Domestik Bruto (PDB) mencapai 61,07\% atau senilai Rp8.573,89 triliun dengan jumlah UMKM sebanyak 64,2 juta (kemenkopukm.go.id). Para pelaku UMKM saling bersaing untuk menghasilkan berbagai jenis produk yang 
bernilai. Hal ini juga dilakukan oleh para pelaku UMKM yang ada di Dusun Dawaunan, Desa Madyocondro.

Desa Madyocondro merupakan salah satu desa di Kecamatan Secang, Kota Magelang, Jawa Tengah dengan jumlah penduduk sekitar 5.774 jiwa. Rata-rata penduduk adalah menengah ke atas dengan jumlah pendapatan Rp1.500.000 sd Rp2.500.000 per bulan. Adapun mata pencaharian penduduk di desa Madyocondro adalah Pegawai Negeri Sipil (PNS), polisi, pedagang, petani, dan peternak.

UMKM yang berdiri di Dusun Dawunan diantaranya adalah UMKM Mirasa yang memproduksi kue nopia (ndog bulus) dan UMKM Berkah Dua Putri yang menghasilkan kue egg roll atau semprong. Kedua UMKM tersebut sudah berdiri sejak lama dan masih menggunakan metode tradisional dalam proses produksinya. Hal ini nampak pada cara pengolahan dan penggunaan peralatan yang masih sederhana. Berdasarkan wawancara dengan pemilik UMKM, penggunaan metode tradisional tersebut ditujukan untuk mempertahankan keaslian rasa kue nopia dan semprong yang tidak berubah sejak dahulu. Namun demikian, dalam perkembangan usahanya, kedua UMKM tersebut menghadapi beberapa masalah. Pertama, pangsa pasar kedua UMKM tersebut masih terbatas. Saat ini, kedua UMKM tersebut hanya memasarkan produknya di sekitar lingkungan tempat produksi, seperti di warung atau di pasar. Pelaku UMKM belum menyadari bahwa dengan menggunakan inovasi pemasaran dengan bantuan teknologi informasi dapat membantu UMKM dalam memperluas pangsa pasar.

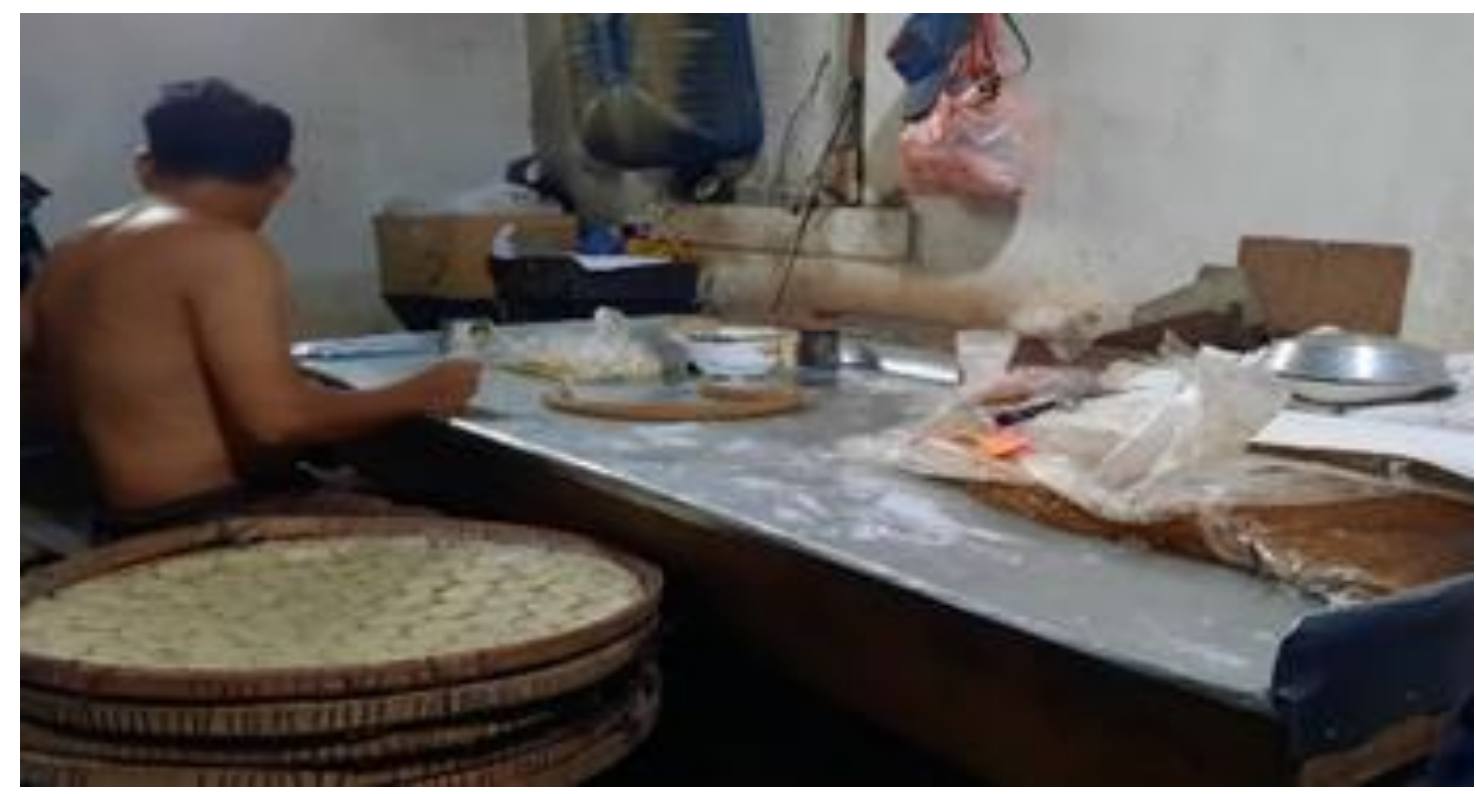

Gambar 1. Proses Produksi Kue Nopia

Permasalahan kedua adalah kurangnya pemahaman kedua UMKM terhadap pentingnya melakukan administrasi keuangan. Andarsari \& Dura (2018) menjelaskan bahwa pembukuan atau pencatatan keuangan sangat bermanfaat terutama dalam hal pengambilan keputusan, permodalan dan perpajakan. Selama ini, kedua UMKM sama sekali tidak melakukan kegiatan pembukuan keuangan, sehingga kedua UMKM tersebut tidak dapat mengetahui dengan pasti jumlah keuntungan yang diperoleh. Selama ini, keuntungan hanya dihitung dengan mengurangi jumlah pendapatan dengan biaya pembelian bahan baku, sementara biaya tenaga kerja, biaya listrik, biaya pemasaran dan 
biaya lainnya tidak dihitung. Hal ini kemungkinan disebabkan kurangnya pengetahuan dan kemampuan pelaku UMKM untuk melakukan kegiatan administrasi keuangan. Belum berjalannya mekanisme administrasi keuangan ini, berpotensi pada kesalahan menghitung jumlah keuntungan maupun kerugian yang ditanggung.

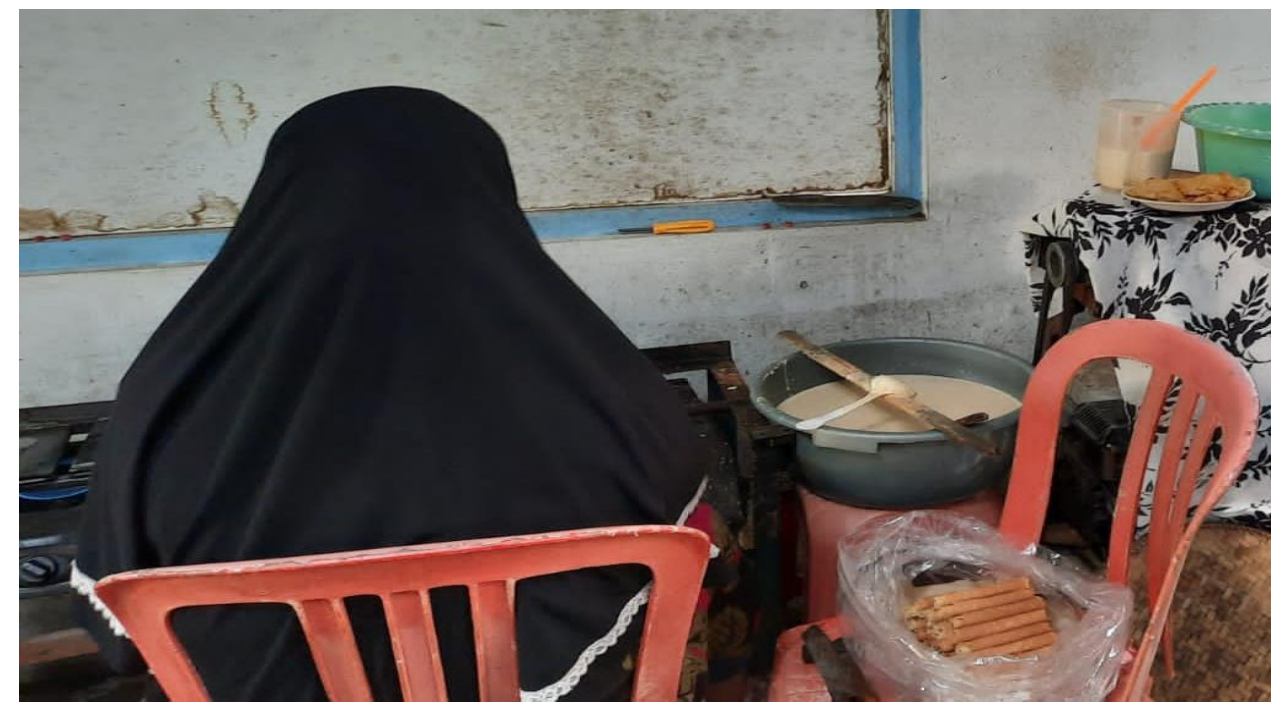

Gambar 2. Proses Produksi Kue Semprong (Egg RoII)

Permasalahan ketiga adalah kurangnya kesadaran dan pemahaman UMKM Mirasa dan UMKM Berkah Dua Putri terkait dengan hak kekayaan intelektual. Para pelaku UMKM kurang memahami tentang manfaat, hak dan kewajiban terkait perijinan merek, label halal dan pelanggaran-pelanggaran perijinan merek. Sebagai contoh adalah label halal. Label halal pada kemasan produk bermanfaat dalam menambah keyakinan konsumen untuk membeli atau mengonsumsi produk yang ditawarkan (Rahmawati, 2014 dan Syahir, Ramadhani \& Tarigan, 2016). Adanya label halal pada produk akan membuat masyarakat semakin yakin bahwa produk yang dihasilkan layak untuk dikonsumsi dan terjamin mutu serta keamanannya (pom.go.id).

\section{TINJAUAN TEORITIS}

\section{Pemasaran melalui media sosial}

Pemasaran melalui media sosial telah banyak digunakan oleh para pelaku usaha. Hal ini disebabkan karena pemasaran melalui media sosial memberikan banyak manfaat. Primasari, Wibisono \& Padawangi (2020) menjelaskan bahwa manfaat dari pemasaran melalui media sosial adalah efisiensi, kenyaman, informasi yang lebih kaya, pilihan produk yang lebih luas, harga kompetitif, pengurangan biaya, keragaman produk, kemudahan berkomunikasi dengan konsumen secara langsung tanpa bertatap muka dan kemudahan akses. Hasil penelitian Adrian \& Mulyandi (2021) dan Semuel \& Setiawan (2018) menunjukkan bahwa pemasaran melalui media sosial dapat meningkatkan brands awareness bagi konsumen yang akan berdampak pada peningkatan penjualan di masa depan dan dapat menjangkau calon pelanggan lebih luas. Meskipun dari segi kemudahan dan kebermanfaatan dapat membantu pengguna. Media sosial yang biasa digunakan untuk pemasaran diantaranya adalah facebook, instagram, whatsapp, amazon, dsb. 


\section{Pembukuan keuangan}

Pembukuan keuangan berperan penting dalam pengelolaan usaha terutama UMKM. Pembukuan keuangan bermanfaat untuk pengambilan keputusan investasi, pembiayaan, pembelian aset, pemenuhan kewajiban perpajakan, dsb. Pembukuan keuangan meliputi kegiatan pembuatan pencatatan transaksi dan laporan keuangan. Laporan keuangan untuk UMKM lebih sederhana daripada laporan keuangan perusahaan (Fauzi, 2020). Laporan keuangan untuk UMKM meliputi laporan laba rugi, laporan perubahan ekuitas, neraca dan laporan arus kas. Laporan laba rugi berfungsi untuk menghitung jumlah laba atau rugi yang diperoleh dari pendapatan dikurangi biaya. Laporan perubahan ekuitas berfungsi untuk menyediakan informasi perubahan jumlah modal yang diakibatkan adanya laba atau rugi yang terjadi setelah dikurangi pengabdian pribadi oleh pemilik. Neraca menunjukkan posisi aset, hutang dan modal. Jumlah keseluruhan aset harus seimbang atau sama dengan jumlah hutang dan modal. Sementara laporan arus kas menunjukkan informasi pemasukan dan pengeluaran kas, sehingga bisa diketahui jumlah kas akhir yang dimiliki oleh UMKM.

\section{Hak Kekayaan Intelektual}

Kekayaan intelektual merupakan hasil pemikiran dan kecerdasan manusia yang diwujudkan dalam bentuk penemuan, desai, seni, karya tulis atau penerapan praktis suatu ide yang mengandung nilai ekonomis (Khairunnisa, 2019). Hak kekayaan intelektual adalah hak eksklusif yang diberikan kepada kreator, inventor atau pendesain atas hasil kreasi atau temuannya yang bernilai komersial oleh negara, baik yang diperoleh secara langsung (otomatis) atau melalui mekanisme pendaftaran pada instansi terkait sebagai penghargaan atau pengakuan hak yang dilindungi oleh hukum (Mulyani, 2012).Hak kekayaan intelektual meliputi hak paten, hak cipta, dan hak merek dagang. Penggunaan hak kekayaan intelektual dilindungi oleh hukum, sehingga pelanggaran atas penyalahgunaan dapat dikenai sanksi hukum.

\section{METODE PENGABDIAN}

Berdasarkan permasalahan yang di hadapi UMKM Mirasa dan UMKM Berkah Dua Putri tersebut, maka pada kegiatan pengabdian kepada masyarakat ini dilakukan edukasi, pelatihan, dan pendampingan terkait dengan pengembangan model pemasaran, administrasi keuangan dan hak kekayaan intelektual. Tujuannya adalah agar pemahaman dan pengetahuan pelaku UMKM Mirasa dan UMKM Berkah Dua Putri terkait dengan pengembangan model pemasaran, administrasi keuangan dan hak kekayaan intelektual dapat meningkat. Metode atau tahapan kegiatan yang dilakukan pada program pengabdian di UMKM Mirasa dan UMKM Berkah Dua Putri ini adalah observasi, sosialisasi, pelatihan, pendampingan dan evaluasi. Gambaran terperinci terkait kegiatan pengabdian yang dilaksanakan adalah sebagai berikut:

1) Observasi

Tahap observasi pada UMKM Mirasa dan UMKM Berkah Dua Putri ditujukan untuk mengetahui lebih jelas terkait dengan proses bisnis yang dilakukan oleh kedua UMKM mulai dari proses produksi, pengemasan, pemasaran dan pencatatan keuangan.

2) Sosialisasi

Pada tahap sosialisasi, pelaku UMKM diberikan materi terkait dengan model pemasaran produk dengan menggunakan teknologi, khususnya terkait dengan 
pemanfaatan media sosial seperti facebook dan instagram. Materi yang diberikan selanjutnya adalah terkait dengan pencatatan keuangan sederhana seperti pencatatan transaksi dalam jurnal dan pembuatan laporan keuangan (laporan laba/rugi, perubahan ekuitas dan neraca). Kemudian, pelaku UMKM diberikan materi terkait dengan manfaat dan pentingnya melakukan perijinan merk dagang dan label halal pada produk.

3) Pelatihan

Pada tahap pelatihan, pelaku UMKM Mirasa dan UMKM Berkah Dua Putri dilatih cara mengoperasikan facebook dan instagram sebagai media pemasaran, mulai dari membuat akun, memposting produk, memberikan deskripsi pada produk dan cara bagaimana merespon pesan jika ada yang memesan produk melalui fasilitas pesan pada akun facebook atau instagram. Selanjutnya, pelaku UMKM dilatih cara membuat pembukuan keuangan, mulai dari pencatatan transaksi ke dalam jurnal, pembuatan laporan laba/rugi, perubahan ekuitas dan neraca.

4) Pendampingan

Pada tahap pendampingan, pelaku UMKM Mirasa dan UMKM Berkah Dua Putri didampingi dalam proses pengoperasian media sosial yang telah dibuat dan proses pembuatan pembukuan keuangan.

5) Evaluasi

Keseluruhan kegiatan yang dilaksanakan oleh pelaku UMKM kemudian dievaluasi untuk mengukur sejauh mana pengetahuan dan pemahaman pelaku UMKM terkait dengan materi dan praktek yang telah dilakukan. Evaluasi ini dilakukan dengan wawancara konfirmasi pemahaman materi yang telah diberikan dan observasi secara langsung terhadap penggunaan media sosial sebagai media pemasaran dan proses pembukuan keuangannya.

\section{HASIL DAN PEMBAHASAN}

Program Pengabdian Pada Masyarakat ini bertujuan untuk membantu memecahkan masalah yang dihadapi UMKM Mirasa dan UMKM Berkah Dua Putri terkait dengan pengembangan model pemasaran, pembukuan UMKM sederhana dan penyuluhan hak kekayaan intelektual. Pemilik UMKM Mirasa adalah Ibu Wahyu Istriani dan pemilik UMKM Berkah Dua Putri adalah Bapak Partono. Pelaksanaan kegiatan pengabdian dilakukan di Dusun Dawunan, Desa Madyocondro, Kecamatan Secang, Kota Magelang, Provinsi Jawa Tengah. Kegiatan pengabdian dilaksanakan selama 4 bulan, mulai dari bulan November 2021 sampai Februari 2022.

Adapun kegiatan pengabdian dimulai dengan koordinasi penyelenggaraan yang dilakukan oleh tim pelaksana dengan kepala Desa Madyocondro dan perangkat desa lainnya. Tujuan dari koordinasi tersebut adalah untuk melakukan pemetaan UMKM di Desa Madyocondro sekaligus meminta ijin terkait pelaksanaan program pengabdian yang akan dilaksanakan. Secara lebih terperinci, pelaksanaan kegiatan pengabdian pada UMKM UMKM Mirasa dan UMKM Berkah Dua Putri adalah sebagai berikut:

1) Observasi

Pada tahap ini, tim pengabdian mengikuti kegiatan produksi Kue Nopia (NDOG BULUS) di UMKM Mirasa dan produksi Kue Egg Roll di UMKM Berkah Dua Putri. Pada tahapan ini, tim pengabdian memperoleh gambaran jelas terkait proses bisnis yang 
dilakukan oleh UMKM Mirasa dan UMKM Berkah Dua Putri. Proses bisnisnya dimulai dari pembelian bahan baku, proses produksi, pengemasan, dan pemasaran.

Pada UMKM Mirasa, setelah bahan baku diperoleh, selanjutnya adalah proses produksi kue nopia. Proses produksi dimulai dari pembuatan adonan kulit nopia dari tepung terigu dan gula pasir, sementara untuk isiannya adalah adonan tepung terigu dicampur gula jawa. Setelah kulit nopia dan isian selesai dibuat, kemudian proses pencetakan dengan cara membungkus isian nopia dengan kulit nopia. Setalah cetakan kue nopia selesai dibuat, kemudian kue nopia dipanggang di dalam tungku atau gentong yang sebelumnya sudah dipanasi selama kurang lebih 30 menit. Setelah cetakan kue nopia berwarna kecoklatan, kue nopia diangkat dan didinginkan. Selanjutnya, kue nopia dikemas dan dipasarkan ke warung terdekat dan dijual ke pasar.

Proses bisnis di UMKM Berkah Dua Putri tidak jauh berbeda dengan proses bisnis di UMKM Mirasa. Proses bisnis dimulai dari pembelian bahan baku, proses produksi, pengemasan dan pemasaran. Pada proses produksi, semua adonan tepung terigu, telur, santan, gula, garam dan wijen dicampur. Adonan berbentuk agak cair. Setelah adonan jadi, adonan di tuang ke dalam wajan teflon, dibiarkan sebentar lalu digulung menjadi bentuk roll. Proses pemanggangan adonan kue semprong dilakukan dengan cepat, agar kue semprong tidak terlalu berwarna cokelat. Setelah proses pemanggangan selesai, kue semprong diangkat dan didinginkan, kemudian dikemas dalam kemasan plastik. Selain dijual per kemasan plastik, kue semprong juga dijual dalam bentuk kardus yang isinya terdiri dari 20 kemasan plastik kue semprong. Selanjutnya, kue semprong dalam kemasan dijual ke warung terdekat dan ke pasar atau diambil oleh tengkulak makanan oleh-oleh.
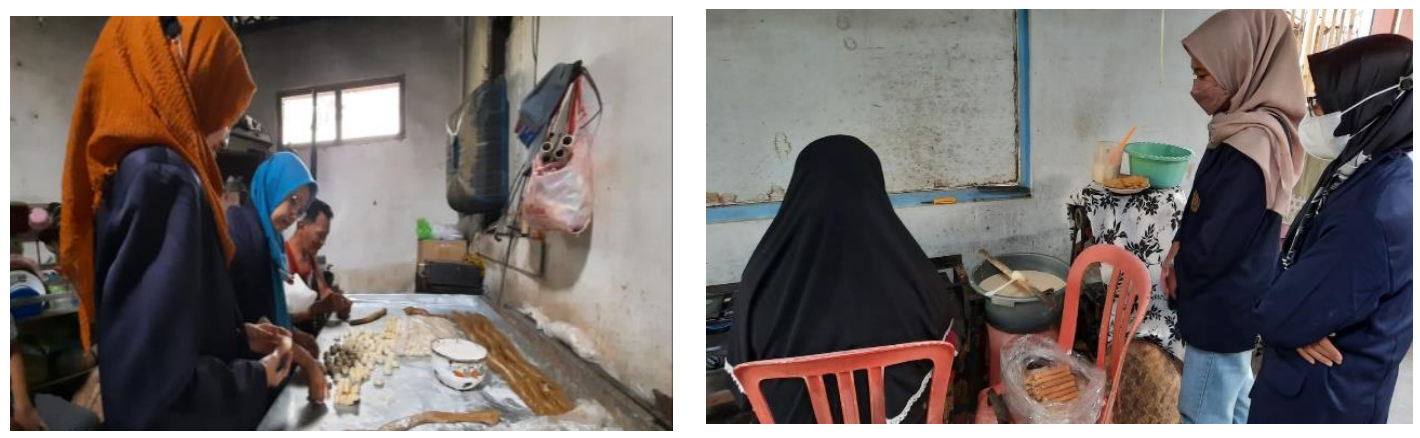

Gambar 3. Observasi kegiatan produksi di UMKM Mirasa dan UMKM Berkah Dua Putri

2) Sosialisasi

Kegiatan sosialisasi yang dilakukan pertama kali adalah sosialisasi pemasaran kepada UMKM Berkah Dua Putri dan UMKM Kue Nopia. Dalam sosialisasi tersebut pelaku UMKM diberikan materi mengenai pemasaran melalui media sosial yaitu instagram dan facebook. Pada tahap ini, tim pengabdian menjelaskan tentang gambaran umum metode pemasaran dengan bantuan teknologi, manfaat pengembangan metode pemasaran, berbagai macam media sosial yang dapat digunakan untuk pemasaran, cara membuat akun di media sosial, cara mengoperasikannya dan cara pengelolaannya.

Kegiatan sosialisasi kedua adalah administrasi keuangan. Pada kegiatan sosialisasi ini, tim pengabdian menyampaikan materi terkait tujuan, manfaat dan cara membuat 
pembukuan keuangan. Pembukuan keuangan sederhana yang dijelaskan kepada pelaku UMKM meliputi pencatatan keuangan atau penjurnalan, laporan laba rugi, laporan perubahan ekuitas, neraca dan laporan arus kas.

Kegiatan sosialisasi ketiga adalah terkait perijinan usaha. Pada tahap sosialisasi ini, pelaku usaha diberikan materi tentang manfaat yang akan diperoleh jika merek dari UMKM sudah terdaftar di Direktorat Jenderal Kekayaan Intelektual (djki). Dari sosialisasi tersebut pemilik usaha menjadi mengerti tentang pentingnya memiliki izin usaha serta mengerti bagaimana cara mendapatkan izin usaha dari djki. Selain itu, pelaku UMKM juga diberikan materi tentang pentingnya memperoleh label halal dan cara memperoleh ijin halal dari Badan Pengawas Obat dan Makanan serta MUI. Adanya label halal dapat menambah keyakinan konsumen untuk membeli atau mengonsumsi kue nopia dan semprong. Dari sosialisasi tersebut pemilik usaha menjadi mengerti tentang jaminan penerapan standar yang sesuai dengan norma agama, industri, dan bisnis. Selanjutnya, pelaku usaha diberikan materi terkait pengaduan kasus atau pelanggaran kekayaan intelektual. Materi yang dijelaskan adalah tentang penanganan plagiasi yang dilakukan orang lain terhadap merek dagang. Dengan sosialisasi tersebut pemilik usaha menjadi mengerti tentang tata cara beracara perdata di pengadilan.
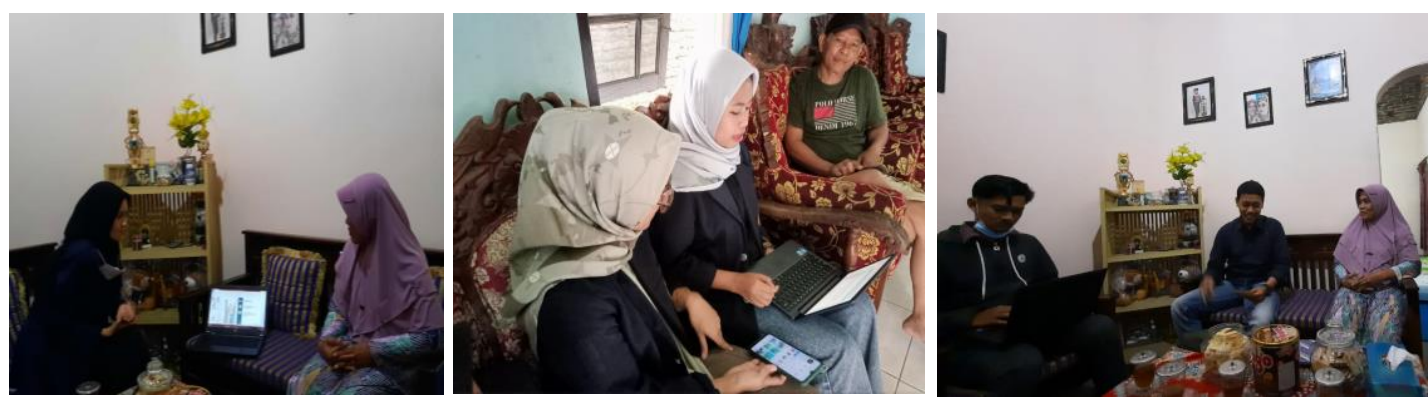

Gambar 3. Sosialisasi Materi Pemasaran Digital, Pembukuan Keuangan dan Hak Kekayaan Intelektual

3) Pelatihan

Pelatihan pada dasarnya adalah tahap implementasi atau tahap praktek dari materi yang diberikan. Implementasi materi pengembangan model pemasaran diawali dengan inovasi pengemasan produk. Inovasi pengemasan produk ini khusus diberikan kepada UMKM Mirasa. Hal ini disebabkan karena kemasan produk kue semprong nampak belum menarik. Oleh karena itu tim pengabdian memberikan desain kemasan produk yang baru berupa stiker yang lebih menarik. Selanjutnya, pelaku UMKM diberikan pelatihan penggunaan bantuan teknologi dalam proses pemasarannya. Para pelaku UMKM dilatih untuk membuat akun di media sosial facebook dan instagram, cara mengoperasikannya, cara memposting dan cara mengelolanya. Dengan demikian pelaku UMKM tersebut dapat memanfaatkan media sosial facebook dan instagram untuk mempromosikan hasil dari produksinya sehingga akan lebih banyak orang yang mengetahui produk tersebut, sehingga diharapkan penjualan dapat meningkat. Pelatihan terakhir adalah pelatihan pembukuan laporan keuangan sederhana dengan tujuan agar para pelaku UMKM mampu menghitung pengeluaran dan pemasukan dari UMKM yang dijalankan dengan lebih rinci. Hasilnya pelatihan pembukuan keuangan ini adalah pelaku UMKM menjadi paham cara membuat pembukuan keuangan 
sederhana dan mengetahui secara pasti jumlah keuntungan yang diperoleh dan jumlah kas masuk dan keluar dari transaksi yang dilakukan.
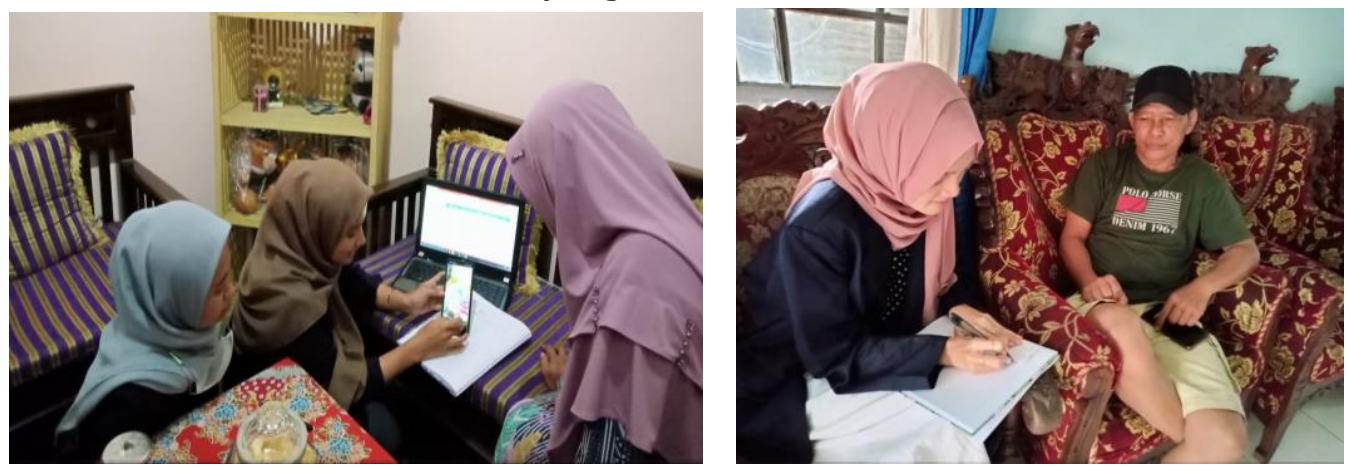

Gambar . Proses Pelatihan Pemasaran Melalui Media Sosial dan Pembukuan Keuangan

4) Pendampingan

Pada tahap ini, para pelaku UMKM yang sudah diberikan materi dan praktik secara langsung, kemudian didampingi untuk keberlanjutan penggunaan media sosial dan pencatatan keuangannya. Pada tahap ini, tim pengabdian memastikan bahwa pelaku UMKM dapat mengoperasikan media sosial facebook dan instagram dalam proses pemasarannya. Kemudian, tim pengabdian juga memastikan bahwa pelaku UMKM dapat mencatat transaksi dengan tepat sesuai dengan jenis transaksi yang dilakukan.

5) Evaluasi

Pada tahap evaluasi, tim pengabdian melakukan wawancara kepada pelaku UMKM untuk mengkonfirmasi seberapa besar pengetahuan dan pemahaman pelaku UMKM terhadap materi yang telah diberikan. Hasilnya menunjukkan bahwa pengetahuan dan pemahaman pelaku UMKM meningkat.

\section{SIMPULAN}

Kegiatan pengabdian di UMKM Mirasa dan UMKM Berkah Dua Putri yang telah dilaksanakan melalui sosialisasi, pelatihan dan pendampingan mampu meningkatkan pengetahuan dan pemahaman pelaku UMKM di Desa Madyocondro. Terdapat peningkatan sikap yang ditunjukkan dari kedua pelaku UMKM setelah diberikan materi dan praktek langsung dari materi. Para pelaku UMKM merasa antusias mengikuti kegiatan pengabdian karena informasi yang disampaikan merupakan informasi baru yang mereka terima dalam kegiatan bisnisnya. Adanya kegiatan ini diharapkan dapat menambah wawasan para mitra tentang pembukuan sederhana UMKM, pemasaran produk dengan memanfaatkan media online facebook dan instagram, serta agar pelaku UMKM lebih mengetahui tentang pentingnya hak kekayaan intelektual seperti ijin usaha, pentingnya label halal dan penanganan plagiasi terhadap merek. 


\section{DAFTAR PUSTAKA}

Adrian, D., \& Mulyandi, M. R. (2021). Manfaat Pemasaran Media Sosial Instagram Pada Pembentukan Brand Awareness Toko Online. Jurnal Indonesia Sosial Sains, 2(2), 215-222.

Andarsari, P. R., \& Dura, J. (2018). Implementasi pencatatan keuangan pada usaha kecil dan menengah. Jurnal Ilmiah Bisnis dan Ekonomi Asia, 12(1), 59-65.

Fauzi, H. (2020). Pelatihan manajemen keuangan bagi pelaku UMKM sebagai upaya penguatan UMKM Jabar Juara naik kelas. BERNAS: Jurnal Pengabdian Kepada Masyarakat, 1(3), 247-255.

Khairunnisa, I. (2019). Hak Kekayaan Intelektual (HKI) Sebagai Objek Waqaf Dalam Hukum Islam. Iqtishaduna, 10(2), 161-172.

Mulyani, S. (2012). Pengembangan Hak Kekayaan Intelektual Sebagai Collateral (Agunan) Untuk Mendapatkan Kredit Perbankan Di Indonesia.Jurnal Dinamika Hukum, 12(3), 568-578.

Primasari, C. H., Wibisono, Y. P., \& Pandanwangi, T. Q. (2020). Social media marketing sebagai sarana peningkatan kualitas pemasaran komunitas umkm paroki st. Antonius kotabaru yogyakarta. Ikra-ith abdimas, 3(3), 97-101.

Rahmawati, V. (2014). Pengaruh Atribut Produk dan Label Halal Sebagai Variabel Moderating Terhadap Keputusan Pembelian Produk Kosmetik Wardah di Kota Semarang. Jurnal Fakultas Ekonomi Dan Bisnis Universitas Dian Nuswantoro, 1-9.

Sahir, S. H., Ramadhani, A., \& Tarigan, E. D. S. (2016). Pengaruh gaya hidup, label halal dan harga terhadap keputusan pembelian kosmetik wardah pada mahasiswa program studi manajemen fakultas ekonomi universitas medan area medan. Jkbm (Jurnal Konsep Bisnis Dan Manajemen), 3(1)

Semuel, H., \& Setiawan, K. Y. (2018). Promosi melalui sosial media, brand awareness, purchase intention pada produk sepatu olahraga.Jurnal Manajemen Pemasaran, 12(1), 47-52. 